\title{
Unemployment and Monetary Policy in Switzerland
}

\author{
Peter Kugler $^{a}$ and George Sheldon ${ }^{b}$
}

JEL-Classification: E24, E31, E50

Keywords: inflation targeting, NAIRU, Phillips curve

\section{Introduction}

In 1999 the Swiss National Bank (SNB) changed its monetary policy from monetary targeting, which it had pursued since the breakdown of the Bretton Woods system, to inflation targeting (IT). ${ }^{1}$ According to the supporters of IT, such a policy shift should have had a number of positive effects in Switzerland, such as reduced and less persistent inflation as well as lower costs of disinflation, the socalled sacrifice ratio. The aim of this paper is to investigate whether these and other effects discussed in the literature did actually arise in Switzerland after the adoption of IT.

Our study breaks new ground in several respects. It is the first to focus on the effects of IT in Switzerland ${ }^{2}$ as most previous empirical work pertains to a time period in which the SNB targeted money and not inflation and Switzerland served as a counterfactual. In addition, unlike previous studies, we use a single modeling framework, the Phillips relationship, in the hope of achieving more uniform and consistent empirical results. Employing a Phillips relationship has the added advantage of providing a link between monetary policy and the labor

a Department of Economics, University of Basel, Peter Merian-Weg 6, PO Box 4653, CH-4002 Basel, Switzerland, www.wwz.unibas.ch/abteilungen/home/abteilung/makro/, Tel.: +41-6126733 44, peter.kugler@unibas.ch.

b Department of Economics, FAI, University of Basel, Peter Merian-Weg 6, PO Box 4653, CH-4002 Basel, Switzerland, www.wwz.unibas.ch/abteilungen/home/abteilung/fai/, Tel.: +41-61-267 33 76, george.sheldon@unibas.ch.

1 The SNB chooses not to term its new policy approach "inflation targeting” as it targets a range of inflation rates $(0-2 \%)$ instead of a single value. However this is the case in almost all countries that are generally considered to be inflation targeters, as EPSTEIN (2007) clearly documents. To simplify the discussion, we shall denote the new policy approach of the SNB as inflation targeting and leave it to others to determine whether the terminology is appropriate.

2 The paper by PÉtersson (2004) is the one exception, but it focuses solely on inflation persistence and does not single out Switzerland in its pooled approach. 
market. This allows us to present the first study that also investigates the effects of adopting IT on the labor market, or more specifically on real-wage flexibility and the non-accelerating inflation rate of unemployment (NAIRU). Our paper also addresses the criticism that estimates of the NAIRU are typically too imprecise (cf. STAIGER et al., 1997, 2001) by using a two-equation model that combines an error-correction scheme with SUR estimation.

The two-equation method proves to be successful. It does indeed yield more precise estimates of the NAIRU. However, the effects we investigate pertain to changes in parameters and not to their levels, and in this regard the precision of our estimates is still wanting. Nevertheless, our results do generally support the claims of supporters of IT, albeit rarely to a statistically significant degree.

The remainder of the paper unfolds as follows. Section 2 reviews current knowledge on the effects of IT. Section 3 lays out our theoretical model. Section 4 explains our econometric approach and discusses data problems. Section 5 gives an overview of current estimates of the NAIRU in Switzerland. Section 6 presents our results, and Section 7 summarizes our findings and concludes.

\section{Current State of Knowledge}

Supporters of IT provide a number of arguments in favor of this monetary policy approach. ${ }^{3}$ For one, they claim that by forcing central banks to commit to a given inflation rate, IT should lower the general level of inflation. Current work provides limited evidence of this effect, however. Laubach and Posen $(1997)^{4}$ conduct tests for structural breaks and generate out-of-sample forecasts in four IT-adopting (Canada, New Zealand, Sweden, UK) and - at the time - nonadopting countries (Australia, Germany, Italy, Switzerland) using a Phillips relationship and find no conclusive evidence that IT lowers the level of inflation, especially when comparing the results for IT-adopting and non-adopting countries. The authors also employ a VAR model and achieve similar results. BALL and SHeridan (2005) investigate the same issue with regard to seven IT-adopting (Australia, Canada, Finland, New Zealand, Spain, Sweden, and the UK) and

3 Cf. Leiderman and Svensson (1995), Bernanke and Mishimin (1997), Bernanke et al. (1999), Schaechter et al. (2000), Corbo et al. (2001), Mishinin and Schmidt-Hebbel (2002), Neumann and Von Hagen (2002), Benati (2003), Goodfriend (2003), and SvensSON and WOODFORD (2005).

4 The results from Laubach and Posen (1997) also appear in Bernanke et al. (1999). 
13 non-adopting countries employing a difference-in-differences approach, albeit without controlling for other covariates, and find no evidence of an inflationlowering effect if one allows for the possibility that inflation is mean reverting.

Supporters of IT further argue that IT should stabilize the inflation expectations of market participants thus making their inflation expectations less dependent on current levels of inflation. The empirical results on this issue are mixed. A number of studies ${ }^{5}$ inspect visually whether private-sector inflation expectations, drawn from surveys or inferred from interest rate spreads, fell by more than realized inflation after the adoption of IT. Here the results are mostly non-supportive. Svensson (1993) finds inconclusive evidence for Canada and mostly non-supporting evidence for New Zealand and Sweden. Ammer and Freeman (1995) take a look at Canada, New Zealand, and the UK and collect no solid evidence that the introduction of IT reduced inflation expectations significantly. FrEEMAN and WiLLis (1995) consider all four countries together and achieve mixed findings. LaUBACH and Posen (1997) widen the sample by including the four non-ITadopting countries Australia, Italy, Germany, and Switzerland as a control group. They find that inflation expectations fell in all countries, whether they adopted IT or not, and thus conclude that IT did not lower inflation expectations.

Hun (1996) applies a more stringent test of the expectations hypothesis by examining the out-of-sample forecast performance of a VAR model of the UK economy for the period prior to the introduction of IT in 1993. He repeats the same exercise for France and the USA, which did not adopt IT but nevertheless experienced low inflation in the 1990s as well. The out-of-sample forecasts perform well in France and the USA but over-predict long-term interest rates in the UK. To the extent that long-term interest rates proxy inflation expectations, the over-prediction of the long-term interest rate can be viewed as evidence that the adoption of IT lowered inflation expectations.

LEVIN et al. (2004) instead regress first differences of inflation expectations at various horizons on three-year moving averages of actual inflation to see whether the impact of current inflation on future inflation has weakened in countries that adopted IT, especially at longer horizons. The authors find this to be true in a comparison of the IT-adopting countries Australia, Canada, New Zealand, Sweden, and the UK with the non-adopting countries France, Germany, Italy, and the Netherlands (all treated as one euro country) along with Japan and the United States over the period 1994-2003.

5 Cf. Svensson (1993), Ammer/Freeman (1995), Freeman/Willis (1995), Laubach/Posen (1997). 
GürKAYNAK et al. (2006) employ two empirically calibrated New Keynesian DSGE models to serve as benchmarks for comparison and, based on their simulations, find that, unlike in the US, economic news has little or no impact on far-ahead forward nominal rates and inflation compensation in the IT-adopting countries Sweden and the UK as one would expect if IT is effective.

Supporters of IT also maintain that by anchoring inflation expectations, IT should weaken the persistence of inflation as agents should discount inflationary shocks more quickly and heavily under such a policy regime. The large majority of empirical studies that have focused on this issue find this to be true. Most base their investigations on autoregressions of inflation. Kuttner and Posen (1995) also include the rate of unemployment in their AR model, essentially converting it into a reduced form Phillips relationship, and apply it to the IT-adopting countries Canada, New Zealand, and the UK. They find clear evidence that the introduction of IT lowered the persistence of IT. SikLOs (1999) focuses solely on the time-series characteristics of inflation but includes the non-IT-adopting countries Germany, Switzerland, and the USA along with the IT-adopting nations Australia, Canada, Finland, New Zealand, Spain, Sweden, and the UK. He finds that inflation persistence did not drop in all IT-adopting countries (Australia being the exception), but when it fell, then only there. PÉTERsson (2004) also concentrates on the time-series properties of inflation, albeit in 21 countries (including Switzerland) that adopted IT by 2002. He pools the data across countries, dividing them in various subsets, and finds clear evidence that the adoption of IT reduced inflation persistence. LEvin et al. (2004) compare the time-series characteristics of inflation in the five IT-adopting countries Australia, Canada, New Zealand, Sweden, and the UK and in the seven non-adopting countries Denmark, France, Germany, Italy, the Netherlands, Japan, and the United States and conclude that adopting IT led to markedly lower persistence of core consumer price inflation.

Cовво et al. (1999) employ a less direct test of weakening persistence by modeling the relative deviations of industrial production, money, consumer prices, interest rates, and the nominal exchange rate from their respective HP trends as a non-structural VAR. They apply their approach to 26 countries in total: 9 ITadopters, 6 later adopters, and 11 non-adopters (including Switzerland). Variance decomposition results indicate that the impact of price shocks on the behavior of inflation changed to a much larger degree among IT adopters, suggesting that IT weakened inflation persistence.

Finally, supporters of IT argue that in anchoring inflation expectations IT should also lower the costs of disinflation, i.e., the sacrifice ratio, as market participants should be better able to distinguish changes in relative prices from 
those in the overall price level. To date, scant evidence exists to verify this. LAUBACH and Posen (1997) test for the effect in two ways. First they calculate sacrifice ratios according to the methodology of BALL (1994) and then on the basis of Phillips-curve estimates. The main difference in the two approaches is that the Phillips-curve approach controls for other effects. Comparing the results of adopting and non-adopting countries lead the authors to conclude that the adoption of IT had no impact on the sacrifice ratio.

In summary, the only conclusive empirical finding is that IT tends to weaken the persistence of inflation. The evidence on the other posited effects, on the other hand, is at best mixed.

\section{Theoretical Model}

Our theoretical model for investigating the effects of IT is based on the Phillips curve. In its most general specification, the Phillips relationship takes the form

$$
\Pi_{t}=\Pi_{t}^{e}+\boldsymbol{\theta}(L) \mathbf{D}_{t}+\gamma(L) \boldsymbol{S}_{t}+\varepsilon_{t},
$$

where

$$
\begin{array}{ll}
\Pi & =\text { rate of inflation, } \\
\Pi^{e} & =\text { private-sector expected inflation rate, } \\
\mathrm{D} & =\text { vector of various demand shocks, } \\
\mathrm{S} & =\text { vector of various supply shocks, } \\
\boldsymbol{\theta}(L), \gamma(L) & =\text { vector of polynomials in the lag operator } L, \\
\varepsilon & =\text { white-noise error term. }
\end{array}
$$

Alternative assumptions regarding the above variables lead to variations on (1). For example, if one assumes that inflation expectations are formed adaptively, $\Pi_{t}^{e}$ converts to $\delta(L) \Pi_{t-1}$. Or if one hypothesizes instead that inflation follows a random walk and that expectations are formed in accordance with the rational expectations hypothesis $(\mathrm{REH}), \Pi_{t}^{e}$ reduces to $\Pi_{t-1}$.

The demand variable can assume various forms as well. Normally it is defined either as the output gap (i.e. the relative deviation of output from its potential or trend level) or as the deviation of the unemployment rate from its equilibrium level or NAIRU. Which of the two variables is chosen should be of no great consequence according to Okun's Law, but we choose unemployment in order to establish a link between monetary policy and the labor market. 
The reciprocal of $\boldsymbol{\theta}(L)$ corresponds to the so-called sacrifice ratio, which measures the loss in output or employment that is necessary to lower the rate of inflation by 1 percentage point. ${ }^{6}$ The sacrifice ratio thus measures the cost of disinflation.

The Phillips curve is essentially a reduced form and thus potentially consistent with any number of theoretical models. In line with the $\mathrm{OECD}^{7}$, we base our Phillips specification on the Battle-of-the-Markups model developed by LAYARD and Nickell (1987) and Layard et al. (1991). At the forefront of the model stand wage negotiations between workers and firms, which are viewed as a contest between the negotiating parties over shares of GDP. In this setting, unemployment serves as the equilibrating force balancing the demands of both sides, thereby preventing a wage-price spiral from ensuing. Note that in contrast to a classical model of the labor market, this framework models wages as a function of unemployment instead of the other way around.

The Battle-of-the-Markups model begins with a wage equation

$$
w_{t}=\alpha_{0}+p_{t}^{e}-\alpha_{1} U R_{t}+\alpha_{2} S L_{t}^{w}+\alpha_{3} S T_{t}^{w} \text {, }
$$

describing the wage-setting behavior of workers, and a price equation

$$
p_{t}=\beta_{0}+w_{t}^{e}-\beta_{1} U R_{t}+\beta_{2} S L_{t}^{p}+\beta_{3} S T_{t}^{p},
$$

characterizing the price-setting behavior of firms. $\alpha_{0}$ and $\beta_{0}$ represent the autonomous wage and price demands of workers and firms, respectively. $w$ is the nominal wage demands of workers, and $p$ the price charged by firms, both in logarithms. $e$ denotes an expected value, and $U R$ the unemployment rate. $\alpha_{1}$ and $\beta_{1}$ are both positive and measure the degree to which the negotiating parties are willing to back down from their price and wage demands in the face of rising unemployment and, by extension, falling sales. Supply shocks $S$ consist of transitory $(S T)$ and long-term shocks $(S L)$, which pertain either to the wage equation $\left(S T^{w}, S L^{w}\right)$ or the price equation $\left(S T^{p}, S L^{p}\right)$. Transitory shocks are assumed to have zero ex-ante expectation and to consist of cost-push factors such as increases in food and oil prices, taxes, and exchange rates or slowdowns in productivity

6 This definition differs somewhat from the original concept of BALL (1994). Roughly speaking, Ball defines the sacrifice ratio as the peak-to-trough relative loss in trend GDP divided by the corresponding drop in inflation and thus is more descriptive than the regression-based definition employed above.

7 See Richardson et al (2000). 
growth, which narrow the distributional aspirations of the negotiating parties. The above equations imply that the negotiating parties try to recover these losses $\left(\alpha_{3}, \beta_{3}>0\right)$ through their wage and price demands. Long-term or permanent shocks, on the other hand, encompass structural and institutional factors such as the generosity of unemployment insurance, the amount of mismatch between the unemployed and vacancies, or the degree of competition, all of which influence the general efficiency of labor and goods markets.

Combining (2) and (3) and solving for the unemployment rate yields the equation for the current rate of unemployment:

$$
U R_{t}=\frac{\left.\begin{array}{c}
\left(\alpha_{0}+\beta_{0}\right)-\left(w_{t}-w_{t}^{e}\right)-\left(p_{t}-p_{t}^{e}\right) \\
+\alpha_{2} S L_{t}^{w}+\alpha_{3} S T_{t}^{w}+\beta_{2} S L_{t}^{p}+\beta_{3} S T_{t}^{p}
\end{array}\right]}{\alpha_{1}+\beta_{1}} .
$$

The equilibrium unemployment $U R^{*}$ rate is then defined as a situation in which price and wage expectations are met [i.e. $\left(w_{t}-w_{t}{ }^{9}\right)=\left(p_{t}-p_{t}{ }^{9}\right)=0$ ] and transitory shocks are equal to their zero expected values $\left(S T^{w}=S T^{p}=0\right)$, i.e., they do not arise. In this case, (4) converts to

$$
U R_{t}^{*}=\frac{\left(\alpha_{0}+\beta_{0}\right)+\alpha_{2} S L_{t}^{w}+\beta_{2} S L_{t}^{p}}{\alpha_{1}+\beta_{1}} .
$$

The equilibrium rate of unemployment is the rate that balances the distributional demands of workers and firms. As the above equation indicates, the equilibrium unemployment rate depends on the autonomous wage and price demands of the negotiating parties $\left(\alpha_{0}, \beta_{0}\right)$, their willingness to concede $\left(\alpha_{1}, \beta_{1}\right)$ in the face of mounting unemployment, and the efficiency of labor $\left(\alpha_{2} S L^{u}\right)$ and goods markets $\left(\beta_{2} S L^{p}\right)$. According to (5), high autonomous demands, an unwillingness to acquiesce, and inefficient markets lead to high equilibrium unemployment in the Battle-of-the-Markups model.

A Phillips relationship can be derived from the above model by first observing that such a relationship also applies to disequilibrium situations in which UR does not equal UR*. On the basis of (4) and (5), this implies that

$$
U R_{t}-U R_{t}^{*}=\frac{-\left(w_{t}-w_{t}^{e}\right)-\left(p_{t}-p_{t}^{e}\right)+\alpha_{3} S T_{t}^{w}+\beta_{3} S T_{t}^{p}}{\alpha_{1}+\beta_{1}} .
$$


To keep the notation simple, we assume for the purposes of illustration that the deviations of wages and prices from their respective expected values are approximately equal [i.e. $\left.\left(w_{t}-w_{t}\right)=\left(p_{t}-p_{t}\right)\right]$, that inflation follows a random walk $\left(\Pi_{t}=\Pi_{t-1}+\varepsilon\right)$, and that market participants adhere to the REH. ${ }^{8}$ In this case, (6) converts to

$$
\Pi_{t}-\Pi_{t-1}=-\frac{\left(\alpha_{1}+\beta_{1}\right)}{2}\left(U R_{t}-U R_{t}^{*}\right)+\frac{\alpha_{3}}{2} S T_{t}^{w}+\frac{\beta_{3}}{2} S T_{t}^{p}+\varepsilon_{t} .
$$

Then replacing the equilibrium rate of unemployment with its equivalent in accordance to (5) yields

$$
\begin{aligned}
\Pi_{t}-\Pi_{t-1}= & \frac{\left(\alpha_{0}+\beta_{0}\right)}{2}-\frac{\left(\alpha_{1}+\beta_{1}\right)}{2} U R_{t} \\
& +\frac{\alpha_{2}}{2} S L_{t}^{w}+\frac{\beta_{2}}{2} S L_{t}^{p}+\frac{\alpha_{3}}{2} S T_{t}^{w}+\frac{\beta_{3}}{2} S T_{t}^{p}+\varepsilon_{t},
\end{aligned}
$$

which is essentially the Phillips relationship given in (1), albeit without the lag operators and under the assumption that $\Pi_{t}^{e}=\Pi_{t-1}$.

The coefficient of the demand variable $U R$ in equation (8) indicates that the source of a high sacrifice ratio, or costs of disinflation, is an unwillingness (low values of $\alpha_{1}$ and $\beta_{1}$ ) of the wage negotiators to relinquish on their wage and price demands in the light of increasing unemployment.

The NAIRU is derived from a Phillips relationship by imposing the NAIRU condition that the rate of inflation remain constant $\left(\Pi_{t}=\Pi_{t-1}\right)$, by setting any transitory shocks equal to their zero expected values, and by solving for the unemployment rate. Applying these conditions to (8) yields

$$
\mathrm{NAIRU}=\frac{\left(\alpha_{0}+\beta_{0}\right)+\alpha_{2} S L_{t}^{w}+\beta_{2} S L_{t}^{p}}{\alpha_{1}+\beta_{1}}
$$

8 Assuming instead that inflation is stationary and that inflation expectations are formed adaptively complicates matters by adding lagged values of the inflation rate to the Phillips relationships (7) and (8) and a multiplicand, consisting of 1 minus the sum of coefficients on lagged inflation, to the denominator in (9). 
Comparison of (5) with (9) indicates that the equilibrium unemployment rate in the Battle-of-the Markups model is equal to the NAIRU derived from a Phillips curve. Moreover, we see that from the perspective of the Battle-ofthe Markups model, the NAIRU varies with the autonomous wage and price demands of the negotiating parties $\left(\alpha_{0}, \beta_{0}\right)$, their unwillingness to relinquish on these demands $\left(\alpha_{1}, \beta_{1}\right)$ in the face of mounting unemployment, and the inefficiency of labor $\left(\alpha_{2} S L^{w}\right)$ and goods markets $\left(\beta_{2} S L^{p}\right)$. Increases in these factors raise the NAIRU.

The denominator in (9) is also viewed in the literature as a measure of real wage flexibility, understood as the sensitivity of the real wage to changes in unemployment. The reasoning behind this becomes apparent if one solves for the $\log$ of the real wage in equations (2) and (3). Viewed from this angle, low real wage flexibility is a cause of a high NAIRU. It also implies high costs of disinflation.

Real-wage flexibility $\left(\alpha_{1}+\beta_{1}\right)$ is also the channel through which monetary policy affects unemployment in our model. We argue that a credible inflation target should convince wage negotiators that wage-price battles will not be accommodated by the central bank and thus will threaten employment and sales, thereby increasing the sensitivity of their wage and price demands to changes in unemployment. Increases in real-wage flexibility in turn will lower the NAIRU and reduce the costs of disinflation, i.e., the sacrifice ratio.

\section{Econometric Model}

Our econometric model consists of the two-equation system

$$
\begin{aligned}
\Pi_{t} & =a_{0}-\frac{\lambda}{2}\left(U R_{t-1}-U R_{t-1}^{*}\right)+\sum_{i=1}^{n}\left(a_{i} \Pi_{t-i}+b_{i} \Pi_{c, t-i}\right)+\varepsilon_{1 t} \\
U R_{t} & =U R_{t}^{*}+\sum_{i=1}^{m} c_{i}\left(U R_{t-i}-U R_{t-i}^{*}\right)+\varepsilon_{2 t},
\end{aligned}
$$

combined with the following equation for the NAIRU

9 See, for example, LAYARD et al. (1991), p. 57. 


$$
U R_{t}^{*}=\left(c_{0}+\sum_{j=1}^{p} d_{j} X_{j, t}\right) / \lambda .
$$

Equation (10) corresponds to (7) in our theoretical model. It slightly re-parameterizes (7) by replacing real wage flexibility $\left(\alpha_{1}+\beta_{1}\right)$ with $\lambda$. Also unlike in (7), we do not assume rational expectations or that inflation follows a random walk. Consequently, lagged inflation appears in (10) and undifferenced. On the basis of Figure 1, which plots the monthly rate of change in the seasonally adjusted CPI, realized inflation does indeed appear to be stationary, after taking a break in the mid 1990s into account. And in fact, a Phillips-Perron test rejects the I(1) hypothesis at the $1 \%$ level, while a KPSS test fails to reject the null of stationarity at any reasonable significance level for the two sample periods.

The distributed lag of changes in commodity prices $\Pi_{c}$ expressed in Swiss francs in (10) is meant to capture transitory cost shocks $S T$. Real commodity prices and the real effective exchange rate were also considered as potential candidates but were later dropped after they failed to improve the model fit.

Our Phillips relationship departs from previous specifications in that it defines the demand variable in terms of deviations of the observed unemployment rate from its equilibrium value. This introduces an error-correction term, absent in previous specifications. The usual procedure is instead to replace the equilibrium unemployment rate by an equation such as (5) so that only observed unemployment appears in (10).

Equation (11) specifies the unemployment rate to be a linear function of the equilibrium unemployment rate, a lagged distribution of past deviations of the observed unemployment rate from its equilibrium level, and an error term. Including (11) greatly simplifies the estimation of NAIRU since it reduces the number of parameter estimates that enter into the calculation of the NAIRU. This becomes apparent if one substitutes (11) and (12) into (10), as is usually done, and then solves for the NAIRU. Making NAIRU a function of fewer parameters should also improve the efficiency of its estimate.

Equation (12) defines the equilibrium unemployment rate in accordance with equation (5) as a function of permanent supply shocks $X$ that affect the efficiency of the labor market. A comparison of (12) with (5) shows that $c_{0}$ equals $\alpha_{0}+\beta_{0}$, the sum of the autonomous wage and price demands of workers and firms, respectively.

We considered various potential candidates for permanent supply shocks. One is the maximum duration of unemployment insurance (UI) benefits. As Figure 2 shows, benefit durations have been extended repeatedly across the years. 
Figure 1: Monthly Inflation in Switzerland, 1980-2009 (CPI, Seasonally Adjusted)

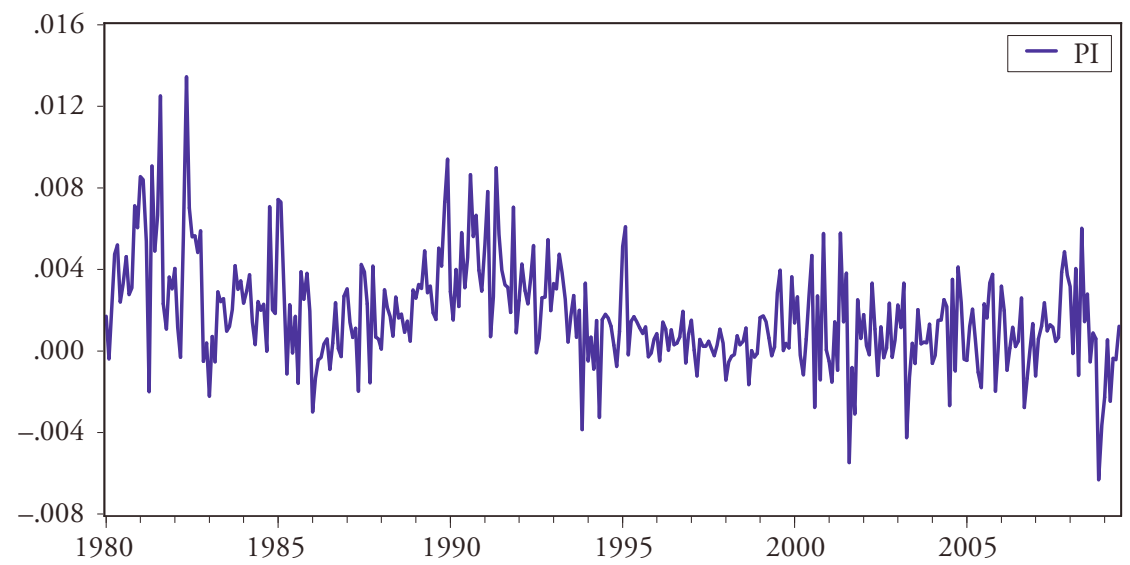

SHELdon (1997) has shown that these extensions have raised the level of baseline employment in Switzerland in the past.

Another possible permanent supply shock is the improvement in the quality of the public employment services since the late 1990s. The some 3000 local employment offices that originally provided public job-placement services were consolidated into roughly 130 regional placement centers (Regionale Arbeitsvermittlungszentren) in 1998. SHELDON (2008) has shown that this move led to a trend increase in the matching efficiency of the Swiss labor market.

Mismatch in the labor market, on the other hand, which could also affect labor market efficiency, gives no indication of a trend change (cf. Figure 3$)^{10}$. SHELDON (1999) demonstrates that that was also true before 1990. Nor has the amount of structural change in the labor market, as measured by the shift in the distribution of jobs across occupations, changed in the last 30 years (see SHELDON, 2005).

Another possible permanent supply shock is the use of active labor market measures such as retraining and work programs, which increased after the late

10 The mismatch indicator appearing in Figure 4 equals the sum of the absolute differences between the shares of the unemployed and vacancies by occupation, divided by two. The indicator gives the degree to which the relative distribution of the unemployed or vacancies across occupations would need to change to equate the two distributions and thus make for a perfect match. The indicator varies from 0 (perfect match) to 1 (perfect mismatch). 
Figure 2: Unemployment and Length of UI Benefit Entitlement,

Switzerland, 1970-2009

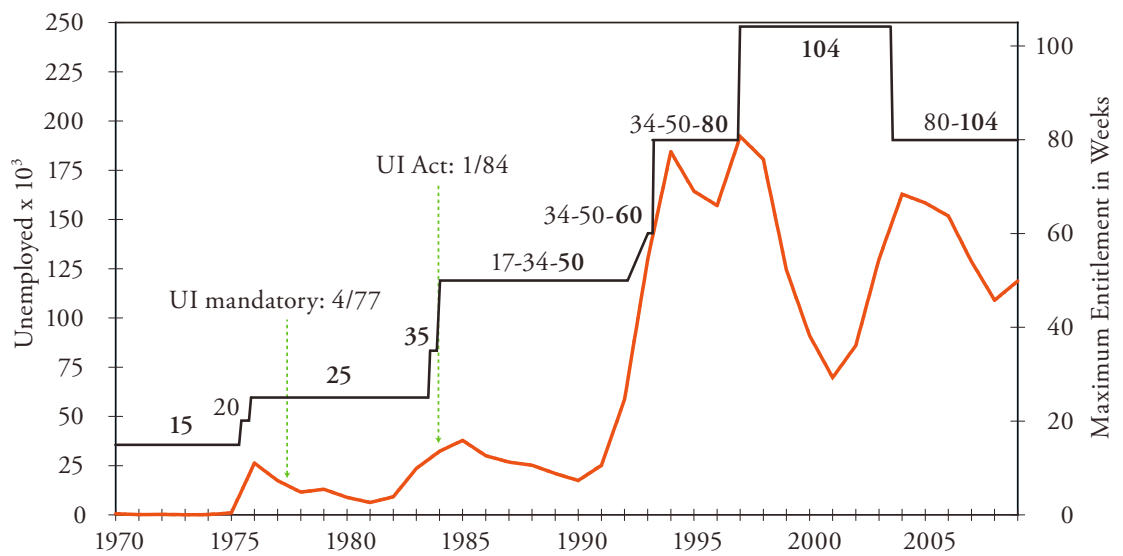

Figure 3: Degree of Occupational Mismatch between the Unemployed and Vacancies, Switzerland, 1990-2008

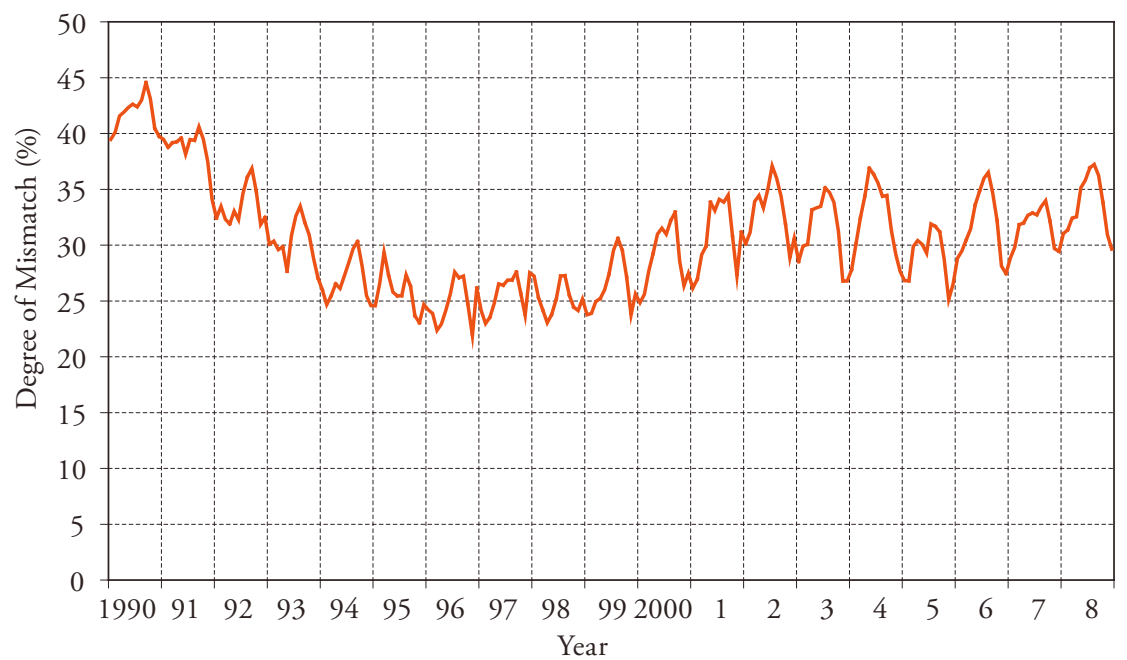


Figure 4: Active Labor Force in Switzerland, 1970-2009

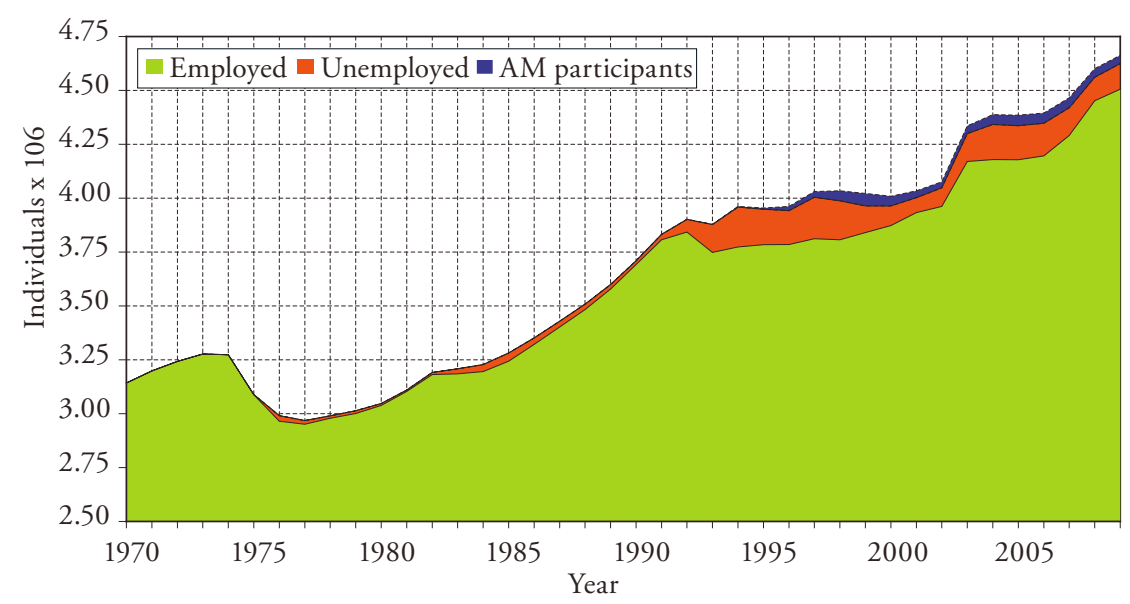

1990s and should have lowered equilibrium unemployment as well. Evaluation studies by among others Gerfin/Lechner (2002) and LaLive et al. (2008) show, however, that these efforts have met with very limited success.

After inspecting the data, we finally chose to consider solely the extensions in the maximum duration of UI benefits as permanent supply-side shocks. Accordingly, the $X$ variables in (12) consist of dummy variables denoting the months in which the duration of UI benefits varied in the sample period

A final issue is the quality of the unemployment data. The unemployment rate series has been subject to a number of breaks since the 1990s, which also need to be taken into account.

- The active labor force, consisting of the sum of employed and unemployed and serving as the denominator of the official unemployment rate, is only updated at ten-year intervals in Switzerland in accordance with the latest census data. Since employment in Switzerland has exhibited a trend increase since the late 1970s (cf. Figure 4), the discontinuous updating of the labor force results in an increasing overestimation of the true amount of slack in the labor market as a decade progresses.

- The share of jobless participating in active measures (AM) and - in line with international convention - not counted as unemployed has been increasing since the mid 1990s. As a result, the official unemployment rate also increasingly underestimates the excess supply in the labor market. 
Figure 5: Monthly Unemployment Rates in Switzerland, 1990-2009 (seasonally adjusted)

— jobless rate — jobless rate controlling for labor force growth

—official figure - official figure controlling for labor force growth

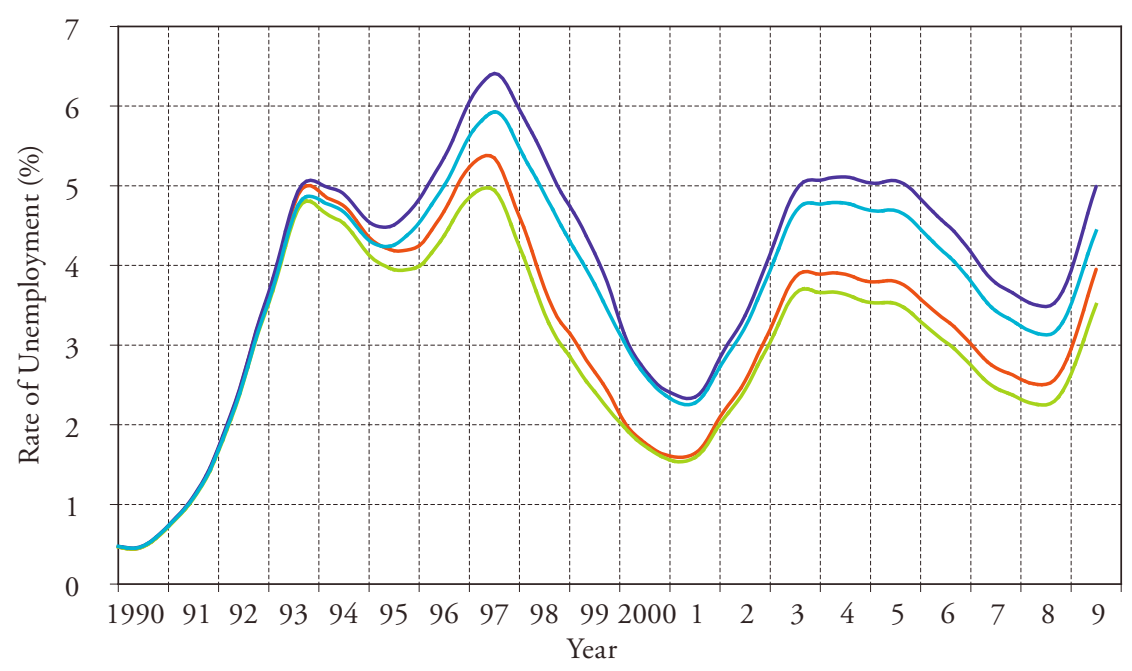

The net effect of both influences can be viewed in Figure 5. The jobless rate includes participants in active labor market measures. The changes pictured in the chart could potentially bias our results. Hence we decided to use all four series and compare results.

What effects should we then expect the adoption of IT to have on our econometric model? As explained in Section 2, supporters of IT generally expect that by making monetary policy more transparent and credible, IT should:

- lower the rate of inflation under otherwise equal conditions,

- weaken the influence of current inflation on expectations of future inflation,

- reduce the amount of persistence in realized inflation, and

- lower the costs of disinflation or the sacrifice ratio. 
These various impacts should, in turn, have the following effects on the Phillips curve.

- Lowering the rate of inflation should cause out-of-sample predictions of Phillips relationships estimated before the introduction of IT to overestimate realized inflation after the policy switch.

- Weakening the influence of current inflation on expectations of future inflation should cause inflation expectations to converge to the inflation target in the long run thereby softening or even eliminating the impact of expected or lagged inflation on actual or current inflation in a Phillips relationship.

- Reducing persistence should lower and shorten the lagged influence of transitory cost shocks on current inflation.

- Lowering the costs of disinflation (sacrifice ratio) should increase real wage flexibility as $\alpha_{1}$ and $\beta_{1}$ (or $\lambda$ ) vary inversely with the sacrifice ratio. In other words, the long-run Phillips curve should become more vertical.

- NAIRU should fall since it varies directly with the sacrifice ratio, which is expected to drop.

\section{Previous Estimates of the NAIRU in Switzerland}

To date, there have been no attempts to investigate these effects of IT in Switzerland. However, estimates of the NAIRU exist, although they are few and generally rather imprecise.

The OECD began to provide estimates of the NAIRU in Switzerland in their Economic Survey series in the early 1990s, but in recent years have discontinued the practice. Their most recent estimates are to be found in Richardson et al. (2000), who assume a time-varying NAIRU. Applying both a Kalman and Hodrick-Prescott multivariate filter to quarterly data spanning the period from 1978:1 to 1999:1, they estimate a NAIRU of $4.1 \%$ and $2.9 \%$, respectively, for the first quarter of 1999, compared to an actual employment rate at the time of around 3\%. The authors do not provide standard errors for their estimates. Given that the unemployment rate averaged about $2 \%$ over the period 2000-03, the estimates seem a bit high.

De Masi and Henry (1996) use a structural approach and base their estimates of the NAIRU on ECM regressions of the wage and price equations, presented respectively in (2) and (3) above, over the period 1975:2-1992:4. The residuals from a regression of the log real wage on the degree of labor market tightness, real unemployment benefits, labor productivity, and the terms of trade (the 
co-integrating vector) serve as the error-correction term in the wage equation. The wage equation also includes one-period lagged inflation, wages, and real unemployment benefits. The price equation, on the other hand, contains lagged terms of the inflation rate, the real exchange rate, the output gap, and residuals from a regression of prices on unit labor costs and the real exchange rate. The authors claim that the unemployment rate did not measure the true tightness of the labor market in the sample period because of the strong pro-cyclical variability of the labor force (cf. Figure 4), which arose from the pro-cyclicality of labor migration and the discouraged-worker effect. To correct for this, they follow CoE (1985) and use the ratio of employed to the labor force (employment rate) in place of the unemployment rate. This does not solve the problem, however, as reliable figures on the number of unemployed are still needed to calculate the size of the labor force (sum of employed and unemployed), which serves as the denominator in both the unemployment and unemployment rate. Based on their approach, the authors arrive at a value of $1.52 \%$ for the NAIRU for 1990-92, compared to an actual average unemployment rate of about $3 \%$ during this period, implying that roughly half of unemployment in this time span was structural. Standard errors are not reported.

Estimating wage and price equations instead of a reduced-form Phillips equation also allows the authors to estimate the degree of real wage flexibility, the denominator of the NAIRU appearing in (9). Their results indicate, perhaps surprisingly, that the real wage flexibility in Switzerland is relatively low. This confirms the findings of COE (1985) for the period 1963-83, but contradicts those of Grubb et al. (1983) for the period 1960-80 and Layard et al. (1991) over the period 1960-90, both of whom use the unemployment rate as their measure of labor market tightness and find that the real-wage flexibility in Switzerland is the highest in the OECD. De Masi and Henry are of the opinion that their and Coe's results are more reliable, but their logic is flawed. They are right that the official unemployment rate underestimated the true loss of jobs, but it nevertheless provided a good measure of labor market tightness since after the redundant foreign workers had emigrated, the excess labor supply virtually disappeared, increasing the tightness of the labor market. Thus there was no need for real wages to adjust downwards. Replacing the unemployment rate with the employment rate falsely suggests that an adjustment was necessary, but that it did not come forth, incorrectly implying that real-wage flexibility was low.

ZanetTI (1998) bases his estimates of the NAIRU on a Phillips relationship in which first differences of the annual inflation rate are regressed on the lagged rate of unemployment, lagged changes in inflation, and the distribution of product-specific price changes as a proxy for supply shocks. The lagged inflation 
terms imply adaptive inflation expectations from the viewpoint of the Battleof-the Markups model. The regression model is applied to four sample periods: 1978:4-1981:1, 1981:1-1990:2, 1990:2-1993:4, and 1993:4-1997:4. Two dummies are included in the last period to control for the effect of the introduction of the VAT in 1995 and the increased use of make-work programs in 1997. His results yield a NAIRU of 2\% for the period 1990:2-1993:4, which meets favorably with the results from De Masi and Henry (1996), and a value of $4 \%$ for the period thereafter, which corresponds closely to the maximum estimate of RicHARDSON et al. (2000) for the first quarter of 1999. His estimates exhibit large standard errors, however, that increase with the size of the estimated NAIRU. The $95 \%$ confidence interval for the $2 \%$ estimate runs from 0 to $2.6 \%$, and for the $4 \%$ estimate from 1.7 to $4.4 \%$.

The NAIRU estimates of VInent (2004) also exhibit large standard errors. His uses an econometric approach similar to that of ZANETTi. He also regresses first differences of the CPI on itself, unemployment, and supply shocks. However, he uses a distributed-lag specification in which the BIC method is employed to determine the number of lags for each regressor. Moreover, his supply-shock variable consists of the difference between food and energy inflation and overall CPI inflation, which seems a bit odd given that the difference corresponds essentially to the level of core inflation, which is commonly not viewed as a shock. In addition, VINENT estimates two time-varying NAIRU models which allow for break points in the Phillips relationship. The one approach models NAIRU as having discrete breaks at unknown points in time, while the other models the breaks as a flexible polynomial. All models are estimated using ordinary least squares over the period 1977:1 to 2001:1. The results for the time-varying NAIRU models indicate that the null hypothesis of a constant NAIRU cannot be rejected at the $10 \%$ level of confidence. Moreover, the standard errors are so large that the 95\% confidence interval encompasses all values of the unemployment rate in the sample period. Hence, one cannot reject the hypothesis that the unemployment rate never diverged from a constant NAIRU from 1977 to 2001.

\section{Results}

Our econometric model consists of the regression equations (10) and (11) after replacing the equilibrium unemployment rate by equation (12). The two equations were estimated jointly using the SUR procedure and taking the crossequation restrictions into account. To measure the effects of the adoption of IT, we estimated the model separately for the sample periods 1980-1999 and 
2000-2009. Inflation is measured with respect to the same month of the previous year, and unemployment is given by the jobless rate. However, the results do not change fundamentally if we use the month to month inflation rate and the official unemployment rate. They are only less statistically significant. Our results appear in Table 1.

Table 1: SUR-Estimates of the Two-Equation System 1980-2009

\begin{tabular}{|c|c|c|c|c|}
\hline \multirow{2}{*}{$\begin{array}{l}\text { Coefficient/Variable } \\
a_{0}\end{array}$} & \multicolumn{2}{|c|}{$\begin{array}{l}\text { Coefficient Estimate } \\
2000-2009\end{array}$} & \multicolumn{2}{|c|}{$\begin{array}{c}\text { Coefficient Estimate } \\
1980-1999 \\
\end{array}$} \\
\hline & 0.00292 & $(0.00104)$ & 0.00157 & $(0.000456)$ \\
\hline$\lambda$ & 0.138 & $(0.0589)$ & 0.0703 & $(0.0194)$ \\
\hline$\Pi_{t-1}$ & 0.691 & $(0.0813)$ & 1.088 & $(0.0684)$ \\
\hline$\Pi_{t-2}$ & 0.345 & $(0.102)$ & -0.177 & $(0.0926)$ \\
\hline$\Pi_{t-3}$ & -0.152 & $(0.0707)$ & 0.0550 & $(0.0430)$ \\
\hline$\Pi_{c, t}$ & 0.00606 & $(0.00286)$ & 0.0151 & $(0.00223)$ \\
\hline$\Pi_{c, t-1}$ & 0.0208 & $(0.00454)$ & -0.00332 & $(0.00375)$ \\
\hline$\Pi_{c, t-2}$ & -0.0220 & $(0.00325)$ & -0.00893 & $(0.00239)$ \\
\hline$c_{0}$ & 0.00565 & $(0.00251)$ & 0.00180 & $(0.00322)$ \\
\hline$d_{83}$ & \multicolumn{2}{|c|}{-} & 0.0000115 & $(0.00138)$ \\
\hline$d_{84}$ & \multicolumn{2}{|c|}{-} & -0.0000315 & $(0.00013838)$ \\
\hline$d_{92}$ & \multicolumn{2}{|c|}{-} & 0.0000333 & $(0.000159)$ \\
\hline$d_{93}$ & \multicolumn{2}{|c|}{-} & 0.0000157 & $(0.00159)$ \\
\hline$d_{97}$ & \multicolumn{2}{|c|}{-} & 0.000183 & $(0.000166)$ \\
\hline$d_{03}$ & 0.0000154 & $(0.000061)$ & \multicolumn{2}{|c|}{-} \\
\hline$U_{t-1}$ & 1.352 & $(0.0817)$ & 1.356 & $(0.237)$ \\
\hline$U_{t-2}$ & 0.121 & $(0.149)$ & 0.0384 & $(0.114)$ \\
\hline$U_{t-3}$ & -0.483 & $(0.0831)$ & -0.448 & $(0.0657)$ \\
\hline$R^{2}(\Pi)$ & 0.899 & & 0.975 & \\
\hline$R^{2}(U)$ & 0.996 & & 0.999 & \\
\hline
\end{tabular}

Note: Standard error in parentheses. 
According to the discussion in Section 4, the adoption of IT should have

- lowered the rate of inflation causing forecasts from models estimated before the introduction of IT to overestimate actual inflation after IT adoption;

- anchored inflation expectations thus weakening the impact of lagged inflation on current inflation;

- reduced the impact of transitory price shocks on realized inflation; and

- increased real-wage flexibility, thereby lowering the costs of disinflation (sacrifice ratio) and the NAIRU.

Our findings tend to support these expected effects, but fail, in general, to provide confirmative evidence. First of all, we observe that the error-correction coefficient $\lambda$ is larger in absolute value in the second period, implying higher real-wage flexibility and thus both a lower sacrifice ratio and NAIRU after the introduction of IT. Yet the change in $\lambda$ is not statistically significant, the corresponding $t$-statistic equaling just 1.09. Moreover, according to our results the NAIRU $^{11}$ actually climbed from $2,9 \%$ to $4,1 \%{ }^{12}$ after the adoption of IT, but not to a statistically significant degree ( $t$-value is 1.02). This suggests that permanent supply shocks after 1999 overrode the NAIRU-lowering effects of IT.

Secondly, our results indicate that inflation persistence fell after the introduction of IT as the sum of the lagged inflation terms dropped from 0.97 to 0.88 . Moreover, the difference is significant at the $5 \%$ level of significance (one-tailed test with a $t$-value of -1.61). This conforms to expectations. On the other hand though, the cumulative impact of lagged commodity price shocks increased from 0.00285 to 0.00486 , implying that the impact of transitory price shocks on realized inflation increased after the adoption of IT, which runs counter to expectations. However, the effect is not significant at the $10 \%$ level of significance ( $t$-value is 1.23).

Thirdly, the out-of-sample forecasts (cf. Figure 6) of inflation based on the model estimates from the sample period 1980-1999 and an exogenously given time path for the rate of change in commodity prices all lie above the observed

11 An estimate of the NAIRU is obtained by dividing $c_{0}$ or the sum of $c_{0}$ and an appropriate number of dummy-variable coefficients $d$ by $\lambda$.

12 A NAIRU of 4,1\% may seem high, but note that our estimate pertains to the jobless rate, which lies about 1 percentage point above the official unemployment rate. The current estimate of the equilibrium unemployment rate based on Beveridge curve estimates lies at about $3.3 \%$ in terms of the official unemployment rate, so our results conform well with previous findings. 
Figure 6: Monthly Inflation in Switzerland, Actual (2000-2009) and 1980-99

Model Forecasts (CPI, Month of Previous Year)

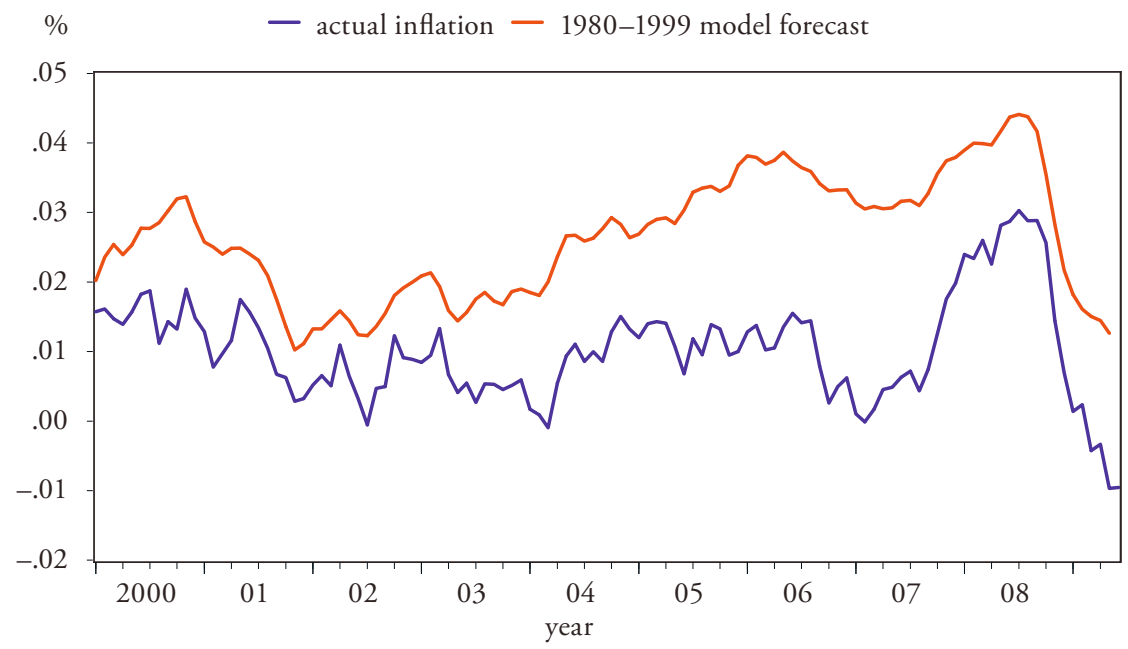

rate of inflation in the period 2000-2009, which implies that IT not only lowered the persistence of inflation but its level as well. But again, the differences are not statistically significant.

\section{Conclusions}

Our paper has investigated the effects of the introduction of IT in Switzerland on the level and persistence of inflation as well as on real-wage flexibility, the sacrifice ratio, and the NAIRU on the basis of a Phillips relationship. The majority of our results suggest that adopting IT lowered the level and persistence of inflation, increased real-wage flexibility and lowered the NAIRU and the costs of deflation. However, only the results pertaining to reduced inflation persistence proved to be statistically significant. Our findings agree generally with the results obtained in other IT-adopting countries. These studies too tend to achieve results that support the positive aspects of IT yet are seldom statistically significant, with the exception of inflation persistence. In their entirety, our results thus suggest that the positive effects of IT are indeed present, but not pronounced enough to achieve statistical significance. 
Our study is of course not without its faults. For one, the Battle-of-the Markups model is not particularly well suited to Switzerland. The model is very corporatist, assuming implicitly that wages are generally negotiated between large workers and employers organizations at the state or national level as, say, in Sweden or in Germany, instead of between workers and their employer at a disaggregate level, which more closely characterizes the Swiss labor market. Future work should attempt to develop a more realistic theoretical model for Switzerland.

Our study also falls short by considering just one possible break point, January 1999. It is undoubtedly unrealistic to assume that the shift from monetary targeting to IT was fully completed within a month. It would thus be interesting to apply econometric methods which endogenize the break point and allow for multiple breaks in the data.

Finally, it might be interesting to try to link the Phillips curve to the Beveridge curve econometrically as DiCKENs (2008) recently attempted. His results suggest that the approach can further raise the precision of NAIRU estimates. Applying his method to Swiss data could thus provide the statistical significance our results lack.

\section{References}

Ammer, J. and R. Freeman (1995), "Inflation Targeting in the 1990's: The Experiences of New Zealand, Canada, and the United Kingdom", Journal of Economics and Business, 47, pp. 165-192.

Ball, L. (1994), “What Determines the Sacrifice Ratio?”, in: N. Mankiw (ed.), Monetary Policy, Chicago: University of Chicago Press, pp. 155-182.

Ball, L. and N. Sheridan (2005), "Does Inflation Targeting Make a Difference?", in: M. Woodford and B. Bernanke (eds), Inflation Targeting, Chicago: University of Chicago Press, pp. 249-76.

Benati, L. (2003), "Evolving Post-World War II U.K. Economic Performance", Journal of Money, Credit, and Banking, 36(4).

Bernanke, B., T. Laubach, F. Mishrin, and A. Posen (1999), Inflation Targeting: Lessons from the International Experience, Princeton, NJ: Princeton University Press.

Bernanke, B., and F. Mishrin (1997), "Inflation Targeting: A New Framework for Monetary Policy?”, Journal of Economic Perspectives, 11, pp.97-116.

Coe, D. (1985), "Nominal Wages, the NAIRU and Wage Flexibility", OECD Economic Studies, No. 5, pp. 87-126. 
Corbo, V., O. Landerretche, and K. Schmidt-Hebbel (2001), "Assessing Inflation Targeting after a Decade of World Experience", International Journal of Finance \& Economics 6(4), pp. 343-368.

Dickens, W. (2008), "A New Method to Estimate Time Variation in the NAIRU”, Paper prepared for the Federal Reserve Bank of Boston's Conference "Understanding Inflation and the Implications for Monetary Policy, A Phillips Curve Retrospective", Northwestern University and Brookings Institution.

Epstein, G. (2007), "Central Banks, Inflation Targeting and Employment Creation", Economic and Labour Market Papers 2007/2, Employment Analysis and Research Unit, Economic and Labour Market Analysis Department, International Labour Office, Geneva.

Freeman, R., and J. Willis (1995), “Targeting Inflation in the 1990s: Recent Challenges", Federal Reserve Board International Finance Discussion Paper No. 525.

Gerfin, M, and M. Lechner (2002). "A Microeconometric Evaluation of the Active Labour Policy in Switzerland", Economic Journal, 112, pp. 854-893.

Goodfriend, M. (2003), "Inflation Targeting in the United States?" in: M. Woodford and B. Bernanke (eds), Inflation Targeting, Chicago: University of Chicago Press, pp. 311-352.

Grubb, D., R. Jackman, and R. Layard (1983), "Wage Rigidity and Unemployment in OECD Countries", European Economic Review, 21(1-2), pp. 11-39.

Gürkaynak, R., A. Levin, and E. Swanson (2006), "Does Inflation Targeting Anchor Long-Run Inflation Expectations? Evidence from Long-Term Bond Yields in the U.S., U.K., and Sweden”, Working Paper No. 2006-09, Federal Reserve Bank of San Francisco.

Hun, C. (1996), Some Evidence on the Efficacy of the UK Inflation Targeting regime: An Out-of-Sample Forecast Approach", Federal Reserve Board International Finance Discussion Paper No. 565.

Kuttner, K., and A. Posen (1999),“Does Talk Matter After All? Inflation Targeting and Central Bank Behavior", Federal Reserve Bank of New York Staff Report No. 88.

Lalive, R., van Ours, J., and J. Zweimüller (2008), “The Impact of Active Labour Market Programmes on The Duration of Unemployment in Switzerland”, Economic Journal, 118, pp. 235-257.

Laubach, T., and A. Posen (1997), "Some Comparative Evidence on the Effectiveness of Inflation Targeting”, Federal Reserve Bank of New York Research Paper No. 9714, New York. 
Layard, R., and S. Nickell (1986), "Unemployment in Britain”, Economica, Supplement, 53, pp. S121-S170.

Layard, R., S. Nickell, and R. Jackman (1991), Unemployment: Macroeconomic Performance and the Labour Market, Oxford: Oxford University Press.

Leiderman, L., and L. Svensson, L. (eds) (1995), Inflation Targets. London: Centre for Economic Policy Research.

Levin, A., F. Natalucci, and J. Piger (2004), "Explicit Inflation Objectives and Macroeconomic Outcomes", European Central Bank Working Paper No. 383, Frankfurt: ECB.

Mishinin, F., and K. Schmidt-Hebbel (2002), "One Decade of Inflation Targeting in the World: What Do We Know and What Do We Need to Know?" in: N. Loayza, R. Soto (eds), A Decade of Inflation Targeting in the World, Santiago: Central Bank of Chile, pp. 117-219.

Neumann, M., and J. von Hagen (2002), „Does Inflation Targeting Matter?”, Federal Reserve Bank of St. Louis Review, 84, pp. 127-148.

PÉtursson, T. (2004), "The Effects of Inflation Targeting on Macroeconomic Performance", Central Bank of Iceland Working Papers No.23, Reykjavík: Central Bank of Iceland.

Richardson, P., L. Boone, C. Giorno, M. Meacci, D. Rae, and D. Turner (2000), "The Concept, Policy Use and Measurement of Structural Unemployment: Estimating a Time Varying NAIRU Across 21 OECD Countries", OECD Economics Department Working Papers, No. 250, Paris: OECD.

Schaechter, A., M. Stone, and M. Zelmer (2000), "Adopting Inflation Targeting: Practical Issues for Emerging Market Countries”, IMF Occasional Paper No. 202.

Sheldon, G. (1997), "Unemployment and Unemployment Insurance in Switzerland", in: P. Bacchetta and W. Wasserfallen (eds), Economic Policy in Switzerland, London: Macmillan, pp. 62-92.

SHELdon, G. (1999), „Arbeitsmarkt, Arbeitslosenversicherung“, in: Kommission für Konjunkturfragen (ed.), Liberales wirtschaftspolitisches Konzept. Materialband, Bern, pp. 1-32.

Sheldon, G. (2005), Der berufsstrukturelle Wandel der Beschäftigung in der Schweiz 1970-2000: Ausmass, Ursachen und Folgen, Bundesamt für Statistik: Neuchâtel.

Sheldon, G. (2008), „Performance der öffentlichen Arbeitsvermittlung der Schweiz im Zeitraum 1998-2007“, Die Volkswirtschaft, 81(11), pp. 52-54.

Siklos, P. (1999), "Inflation-Target Design: Changing Inflation Performance and Persistence in Industrial Countries", Federal Reserve Bank of St. Louis Review March1999, pp.46-58. 
Staiger, D., J. Stock, and M. Watson (1997), "How Precise are Estimates of the Natural Rate of Unemployment?", in: C. Romer and D. Romer (eds), Reducing Inflation: Motivation and Strategy. Chicago: University of Chicago Press, pp. 195-246.

Staiger, D., J. Stock, and M. Watson (2001), "Prices, Wages, and the U.S. NAIRU in the 1990s", in: A. B. Krueger and R. Solow (eds), The Roaring Nineties: Can Full Employment be Sustained?, New York: The Russell Sage Foundation and the Century Foundation Press, pp.3-60.

Svensson, L. (1993), "The Simplest Test of Target Credibility", NBER Working Paper No.4604.

Svensson, L., M. Woodford (2005), "Implementing Optimal Policy through Inflation-Forecast Targeting", in: B. Bernanke and M. Woodford (eds), Inflation Targeting, Chicago: University of Chicago Press.

Vinent, J. (2004), Essays on Production and Business Cycles, Dissertation Nr. 560, University of Geneva.

Zanetri, A. (1998), „Strukturelle Arbeitslosigkeit und Inflation“, Swiss National Bank Quarterly Bulletin, 16(2), pp.45-56.

\section{SUMMARY}

This paper investigates the impact of the monetary policy change of the Swiss National Bank (SNB) in 1999 on the Swiss labor market on the basis of a Phillips relationship. Theoretical considerations as well as previous empirical work suggest that the SNB's shift to a more inflation-targeted policy should have increased real-wage flexibility and lowered the NAIRU, the sacrifice ratio, and the level and persistence of inflation in Switzerland. Our results tend to confirm these expectations, although a number of the measured effects are not statistically significant. 